\title{
SYMBIOTIC CHLOROPLASTS; THEIR PHOTOSYNTHETIC PRODUCTS AND CONTRIBUTION TO MUCUS SYNTHESIS IN TWO MARINE SLUGS
}

\author{
ROBERT K. TRENCH, ${ }^{1}$ MERRILEY E. TRENCH ${ }^{1}$ AND LEONARD MUSCATINE \\ The Marine Laboratory, Discovery Bay, Jamaica; the Department of Agricultural Science, \\ University of Oxford, England and the Zoology Department, University of \\ California, Los Angeles, California 90024
}

Chloroplasts occur within the cells of the digestive diverticulum of some sacoglossan gastropod molluscs (Kawaguti and Yamasu, 1965; Taylor, 1967, 1968, 1970; Trench, 1969; Trench, Greene and Bystrom, 1969; Greene, 1969, 1970). These chloroplasts, derived from certain marine algae (Siphonales) produce oxygen in the light and fix much more ${ }^{14} \mathrm{C}$ in the light than in the dark (Trench, 1969; Trench et al., 1969; Greene, 1969; 1970; Taylor, 1971b).

It has been shown by radioautography that in the sacoglossans Tridachia crispata and Tridachiella diomedea, photosynthetically fixed ${ }^{14} \mathrm{C}$ moves from the chloroplasts to various chloroplast-free animal organs, especially the pedal mucus gland. This gland secretes a carpet of mucus over which the slugs crawl (Trench, 1969; Trench et al., 1969).

Recently, Trench, Trench and Muscatine (1970) showed that after specimens of Placobranchus ianthobapsus (Gould) were incubated in $\mathrm{NaH}^{14} \mathrm{CO}_{3}$ in the light, the mucus secreted by the animals contained ${ }^{14} \mathrm{C}$-galactose and ${ }^{14} \mathrm{C}$-glucose. They suggested that chloroplast photosynthesis provided some of the substrates used by the animal in the synthesis of mucopolysaccharides.

To gain insight into the way sacoglossans utilize the products of chloroplast photosynthesis it is necessary first to identify these products in the animal hosts, and then to follow their incorporation into animal substrates. In addition, by comparing the products of symbiotic chloroplasts in their animal hosts with those of intact siphonous algae, possible modification in chloroplast function in the animal cell milieu may be detected.

This paper compares the products of photosynthetic ${ }^{14} \mathrm{C}$ fixation by chloroplasts in the slugs Tridachia crispata (Mörch) and Tridachiella diomedea (Bergh) with those of chloroplasts in the siphonous marine alga Caulerpa sertularioides. The incorporation of chloroplast products into animal mucus is described in detail and the turnover of ${ }^{14} \mathrm{C}$ in the pedal mucus gland of Tridachia is estimated.

\section{Materials and Methods}

(1.) Collection and maintenance of specimens

Tridachia crispata and Caulerpa sertulariodes were collected from the reefs off Port Royal and Discovery Bay, Jamaica, kept in the shade (about 900-1200 foot candles) in plastic tanks and used within a few days of collection.

${ }^{1}$ Present address: Biology Department, Yale University, New Haven, Connecticut 06520. 
Tridachiella diomedea was collected from mangrove lagoons in the vicinity of La Paz, Baja California, Mexico. Experiments were conducted on board the R. V. Dolphin the same day.

\section{(2.) Experiments}

(a) Incubations in $\mathrm{NaH}^{14} \mathrm{CO}_{3}$. Whole animals and pieces of alga $(2-3 \mathrm{~cm})$ were separately incubated in sea water to which $\mathrm{NaH}^{14} \mathrm{CO}_{3}$ was added to give initial activities of $10-25 \mu \mathrm{c} \mathrm{ml}$. Specimens of Tridachiella diomedea were incubated in sunlight (1000-1500 foot candles in the shade) at a temperature of $21^{\circ} \mathrm{C} \pm 2^{\circ} \mathrm{C}$.

Incubations of Tridachia crispata and Caulerpa sertularioides were carried out under ambient light conditions (900-1700 foot candles) or under constant intensity light conditions of 900 foot candles delivered by photoflood lamps. Temperature was maintained at $25^{\circ} \mathrm{C} \pm 1^{\circ} \mathrm{C}$.

(b) Incubations in ${ }^{3} \mathrm{H}$-leucine. Whole specimens of Tridachia crispata were incubated under conditions similar to those described above for ${ }^{14} \mathrm{C}$ in sea water to which ${ }^{3} \mathrm{H}$-leucine (100-250 mc/mm, Amersham, England) was added to give initial activities of $10-20 \mu \mathrm{c} / \mathrm{ml}$.

\section{(3.) Analytical procedures}

(a) Chemical fractionation of ${ }^{14} \mathrm{C}$-compounds from animal and algal tissues after photosynthetic ${ }^{14} \mathrm{CO}_{2}$ fixation. After incubation in $\mathrm{NaH}^{14} \mathrm{CO}_{3}$, both plant and animal material were extracted under reflux in methanol-chloroform $(1: 2 \mathrm{v} / \mathrm{v})$ for two hours. This fraction was then extracted with diethyl ether in a separatory funnel. Phase separation was effected by the addition of small quantities of $15 \%$ aqueous $\mathrm{NaCl}$. The ether phase was washed with several small aliquots of distilled water, and $100 \mu \mathrm{l}$ was removed for counting. This extracted lipid fraction was deacylated and the products identified as described previously (Trench, 1971a, 1971b).

After withdrawing $100 \mu \mathrm{l}$ of the reconstituted aqueous methanol fraction for counting, the remainder was evaporated to dryness under reduced pressure at $40^{\circ} \mathrm{C}$ and radioactive compounds were recovered in absolute ethanol or dry pyridine. This fraction is referred to as the "intermediary metabolites" fraction. The efficiency of recovery of ${ }^{14} \mathrm{C}$ was $85-95 \%$.

Tissues insoluble in methanol-chloroform were hydrolyzed in $3 \mathrm{~m} \mathrm{KOH}$ in $80 \%$ ethanol. On neutralizing the solution, the precipitate formed was collected by centrifugation. An aliquot of $100 \mu 1$ of the supernatant, the "protein" fraction, was withdrawn for counting, and the remainder was stored for subsequent analysis.

The alkali insoluble precipitate was treated with $1 \mathrm{~m} \mathrm{HCl}$ at $100^{\circ} \mathrm{C}$ for three hours. When neutralized, all the ${ }^{14} \mathrm{C}$ in this fraction from animal tissues was reprecipitated. By contrast, algal tissues were completely solubilized by this treatment. An aliquot of $100 \mu \mathrm{l}$ of algal tissue hydrolysate ("polysaccharide" fraction) was removed for counting. The remainder was stored for subsequent analysis.

The $1 \mathrm{~m} \mathrm{HCl}$ insoluble fraction from animal tissues was hydrolyzed in $3 \mathrm{M}$ $\mathrm{HCl}$ for 4 hours at $100^{\circ} \mathrm{C}$. The solution was neutralized and yielded an insoluble substance which did not dissolve in hot 5\% TCA or hot formic acid. This fraction which contained less than $3 \%$ of the total fixed ${ }^{14} \mathrm{C}$ was not analyzed further. The 
insoluble substance was removed by centrifugation and an aliquot of $100 \mu \mathrm{l}$ of the supernatant (animal "polysaccharide") was collected for counting. The remainder of the samples was stored for subsequent analysis by paper chromatography.

(b) Paper chromatography. Solvent systems used during this study were (i) phenol; water $(100: 40 \mathrm{w} / \mathrm{v})$ for the first dimension and n-butanol: propionic acid:water (142:71:100 v/v) for the second dimension (Bassham and Calvin, 1957) for two dimensional chromatography on Whatman Nos. 1 and 4 papers; (ii) methyl-ethyl-ketone:pyridine: water:acetic acid $(70: 15: 15: 2 \mathrm{v} / \mathrm{v})$, (von Holt and von Holt, 1968b); (iii) n-propanol:ethyl acetate:borated water $(7: 2: 1 \mathrm{v} / \mathrm{v})$ and (iv) pyridine: water: ethyl acetate:acetic acid $(5: 3: 5: 1 \mathrm{v} / \mathrm{v})$, (Block, Durrum and $Z_{\text {weig, }} 1958$ ) ; the latter three systems being used in one dimensional descending chromatography on Whatman No. 1 paper.

Radioactive compounds on developed chromatograms were located by radioautography with Kodak x-ray film and by automatic scanning of one dimensional chromatograms (Loughman and Martin, 1957). Unknown radioactive compounds were identified by "finger-printing" co-chromatography in at least two different solvent systems.

Sugars used in co-chromatography or those produced by hydrolysis of mucus were detected chemically with silver nitrate, $\mathrm{p}$-anisidine hydrochloride or aniline phthalate; amino sugars by the Elson-Morgan reaction (Neuberger and Marshall, 1966).

(c) Gas-liquid chromatography (GLC). Samples of mucus secreted by Tridachia crispata were hydolyzed in $3 \mathrm{M} \mathrm{HCl}$ for 4 hours at $100^{\circ} \mathrm{C}$. The hydrolysates were evaporated to dryness and the trimethyl-silyl derivative produced by adding $0.2 \mathrm{ml}$ bis (trimethyl silyl) acetamide to the dried sample and allowing it to react for 24 hours at $20^{\circ} \mathrm{C}$. Carbohydrates were separated with 2\% SE52 on Diatomite C in a Pye 104 dual FlD gas chromatograph, coupled to a Servoscribe recorder. Peaks were identified by use of internal standards.

(d) Collection of mucus. Mucus was collected from animals by placing individuals in about $2 \mathrm{ml}$ sea water in a beaker and gently swirling the beaker. This caused the secretion over a period of about 10-15 minutes of copious quantities of mucus. After removal of the animal the mucus was precipitated from solution by the addition of an equal volume of absolute ethanol. After cooling to $3^{\circ} \mathrm{C}$, the mucus was sedimented by centrifugation.

(e) Mucus hydrolysis. Samples of mucus secreted by Tridachia and Tridachiella were hydrolyzed in $3 \mathrm{~m} \mathrm{KOH}$ at $100^{\circ} \mathrm{C}$ for 4 hours, and the solution neutralized. The unhydrolyzed polysaccharide was reprecipitated by the addition of absolute ethanol to the neutralized solution at $3^{\circ} \mathrm{C}$, and collected by centrifugation. After several washes with cold $80 \%$ ethanol, the polysaccharide was hydrolyzed with $3 \mathrm{M} \mathrm{HCl}$ for 4 hours at $100^{\circ} \mathrm{C}$. After hydrolysis, this solution was also neutralized. The products of hydrolysis were recovered in absolute ethanol or pyridine for analysis by paper chromatography.

Secreted ${ }^{14} \mathrm{C}$-mucus was precipitated as described above (3d) and hydrolyzed in sealed glass tubes in $3 \mathrm{M} \mathrm{HCl}$ at $100^{\circ} \mathrm{C}$ for 4 hours. The HCI was removed and the solutions were concentrated under vacuum prior to analysis by paper chromatography.

(f) Estimation of total carbohydrate and sulphate in mucus. The carbohydrate content of mucus was estimated using the phenol-sulphuric acid method of Dubois, 
Gillies, Hamilton, Rebers and Smith (1956). Colorimetric measurements were made on a Bausch and Lomb Spectronic-20 spectrophotometer at $490 \mathrm{~nm}$.

The sulphate content of mucus was determined by the method of Gibbons and Wolfrom (1962). Sedimented mucus was dried in vacuo over $\mathrm{P}_{2} \mathrm{O}_{5}$ to constant weight.

(g) Measurement of radioactivity. Radioactive samples were assayed on planchets with a thin end window Geiger-Müller counter. Corrections were made for self-absorption and background.

(h) Tissue radioautography. Animals incubated in $\mathrm{NaH}^{14} \mathrm{CO}_{3}$ or ${ }^{3} \mathrm{H}$-leucine were prepared for radioautography as previously described (Trench et al., 1969). Paraffin-embedded tissues were sectioned at $5 \mu \mathrm{m}$, and were exposed to Kodak AR-10 stripping film at $-5^{\circ} \mathrm{C}$ for 14 to 28 days. Radioautographs were developed as advised by the film manufacturer.

\section{Results}

\section{(1.) Distribution of fixed ${ }^{14} \mathrm{C}$ in Tridachia, Tridachiella and Caulerpa}

After six hours photosynthesis in $\mathrm{NaH}^{14} \mathrm{CO}_{3}$ the distribution of ${ }^{14} \mathrm{C}$ in organic compounds in the two animals was very similar, while both were distinct from the pattern observed in the alga (Table I). Because of the relatively long incuba-

\section{TABLE I}

Percentage distribution of ${ }^{14} \mathrm{C}$ in Tridachia crispata, Tridachiella diomedea and Caulerpa sertularioides after six hours incubation in $\mathrm{NaH}^{14} \mathrm{CO}_{3}$ in the light. $\left(10 \mu \mathrm{c} / \mathrm{ml} \mathrm{NaH}{ }^{14} \mathrm{CO}_{3} ; 900-1000\right.$ foot candles $)$

\begin{tabular}{|c|c|c|c|c|}
\hline & Lipid & $\begin{array}{l}\text { Intermediary } \\
\text { metabolites }\end{array}$ & Protein & Polysaccharide \\
\hline $\begin{array}{l}\text { Tridachia crispata } \\
\text { Tridachiella diomedea } \\
\text { Caulerpa sertulariodes }\end{array}$ & $\begin{array}{ll}10 & (8-12) \\
12 & (9-13) \\
28 & (26-31)\end{array}$ & $\begin{array}{ll}45 & (41-47) \\
40 & (37-43) \\
10 & (9-15)\end{array}$ & $\begin{aligned} 9 & (9-10) \\
8 & (7-9) \\
10 & (9-11)\end{aligned}$ & $\begin{array}{ll}36 & (34-43) \\
40 & (37-43) \\
52 & (47-58)\end{array}$ \\
\hline
\end{tabular}

Values represent averages of four experiments (range in parenthesis). Percentages in animals do not include ${ }^{14} \mathrm{C}$ in mucus secreted during the incubation period.

tion period, it was assumed that the pattern of distribution of ${ }^{14} \mathrm{C}$ in animal and algal tissues approached a "steady state" distribution. Further examination of the composition of these fractions was carried out by paper chromatography.

(a) Lipids. Lipids extracted from the animals yielded, after deacylation, many labelled compounds, among which occurred glycerol and traces of monogalactosylglycerol and digalactosyl-glycerol. These same gylcolipids were also found after deacylation of lipids from Caulerpa but relatively much more ${ }^{14} \mathrm{C}$ was found in mono- and digalactosyl-gylcerol (Table II). It seems reasonable to conclude from these comparisons that the glycolipids are characteristic of plant lipids (see also Thompson, 1965; Nichols, 1970) and that those detected in the animals were probably derived from symbiotic chloroplasts. If this interpretation is accurate, it would suggest that symbiotic chloroplasts only synthesize glycolipid to a limited extent. 
(b) Intermediary metabolites. A wide range of small molecular weight compounds incorporated ${ }^{14} \mathrm{C}$ in the animals and in the alga, the majority of which were distributed amongst the sugar phosphates, amino and carboxylic acids (Table III). Little can be concluded from these data other than the fact that ${ }^{14} \mathrm{C}$ was found mostly in glutamic acid, alanine and succinic acids in both the animals and the plant. The extent to which this may represent dark fixation was not investigated, but dark fixation represents only $4-5 \%$ of photosynthetic fixation (Trench et al., 1969). The remainder of the ${ }^{14} \mathrm{C}$ in this fraction was found principally in carbohydrates, as ${ }^{14} \mathrm{C}$-galactose and ${ }^{14} \mathrm{C}$-glucose in the animals and ${ }^{14} \mathrm{C}$-sucrose and ${ }^{14} \mathrm{C}$-glucose in the alga.

(c) Protein. Relatively small amounts of ${ }^{14} \mathrm{C}$ were detected in animal and plant protein (of Table I). Hyrolysis of animal protein yielded mostly ${ }^{14} \mathrm{C}$-glutamic acid and ${ }^{14} \mathrm{C}$-leucine. Algal protein hydrolysates were not analyzed.

(d) Polysaccharide. When this fraction of animal tissue was hydrolyzed in 3 $\mathrm{M} \mathrm{HCl},{ }^{14} \mathrm{C}$ was found mainly in glucose, galactose, and an unidentified pentose in the ratios of $6: 1: 2$ in Tridachia and $1: 7: 4$ in Tridachiella. This fraction is of interest in that it may represent synthesized but unsecreted mucus. Hydrolysis of Caulerpa polysaccharide yielded ${ }^{14} \mathrm{C}$-glucose, ${ }^{14} \mathrm{C}$-galactose and ${ }^{14} \mathrm{C}$-mannose in the ratio $1: 5: 3$.

These results imply that the fate of photosynthetically fixed ${ }^{14} \mathrm{C}$ in the animals with symbiotic chloroplasts is distinct from that in the alga from which the

\section{TABLE II}

Percentage distribution of ${ }^{14} \mathrm{C}$ in products of deacylated lipids in Tridachia crispata, Tridachiella diomedea and Caulerpa sertularioides after photosynthetic ${ }^{14} \mathrm{C}$ fixation. Experimental conditions and numbers of replications as in Table I.

\begin{tabular}{l|c|c|c|c|c}
\hline \hline & $\begin{array}{c}\text { Mono- } \\
\text { galactosyl- } \\
\text { glycerol }\end{array}$ & $\begin{array}{c}\text { Digalactosyl } \\
\text { glycerol }\end{array}$ & $\begin{array}{c}\text { Sulpholipid } \\
\text { (?) }\end{array}$ & $\begin{array}{c}\text { Glycerol } \\
\text { Unidentified } \\
\text { and } \\
\text { undeacylated } \\
\text { lipid }\end{array}$ \\
\hline Tridachia crispata & 3 & 2 & 15 & 45 & 35 \\
Tridachiella diomedea & 5 & 2 & 10 & 43 & 35 \\
Caulerpa sertularioides & 16 & 19 & 7 & 3 & 55 \\
\hline
\end{tabular}

chloroplasts are derived. This may indicate modification of function by chloroplasts in the animals as well as differences in the utilization of products of choroplast photosynthesis by animal and plant tissues.

\section{(2.) Incorporation of products of chloroplast photosynthesis into animal mucus}

(a) Analysis of mucus secreted by Tridachia and Tridachiella. Under experimental conditions, green specimens of Tridachia containing chloroplasts secreted $300-400 \mu \mathrm{g} / \mathrm{g}$ (fresh weight) $/ \mathrm{hr}$ of mucus (expressed as glucose equivalents), while white animals (presumed to be chlorophyll free) secreted about 100-150 $\mu \mathrm{g} / \mathrm{g} / \mathrm{hr}$.

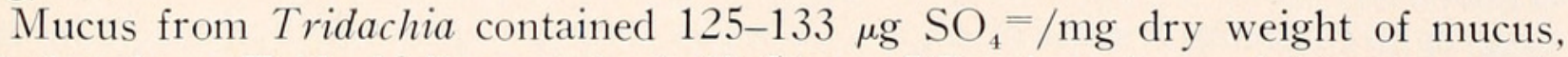
and that from Tridachiella contained 40-54 $\mu \mathrm{g} \quad \mathrm{SO}_{4}=/ \mathrm{mg}$ dry weight mucus. It is not known whether sulphate is present as $\mathrm{N}$-sulphate or $\mathrm{O}$-sulphate or both. 
Analysis of hydrolysates of mucus secreted by Tridachia by paper chromatography and GLC showed glucose, galactose, glucosamine, galactosamine and an unidentified pentose to be present, while hydrolysates of mucus secreted by Tridachiella contained glucose, galactose, possible traces of glucosamine and an unidentified pentose as detected by paper chromatography.

Alkaline hydrolysis of mucus from Tridachia and Tridachiella yielded a series of ninhydrin positive compounds. Although none of these were rigorously identified, compounds behaving chromatographically like leucine and glutamic acid were recognized. It is suggested that these amino acids were derived from the protein associated with the polysaccharide polymer, since it is known that many invertebrate mucins are associated with protein (Hunt, 1970).

(b) Analysis of ${ }^{14} \mathrm{C}$ in secreted mucus. Figure 1 shows the ${ }^{14} \mathrm{C}$-labelled sugars in acid hydrolysates of mucus secreted by Tridachia and Tridachiella under similar experimental conditions. Most of the sugars detected in unlabelled mucus

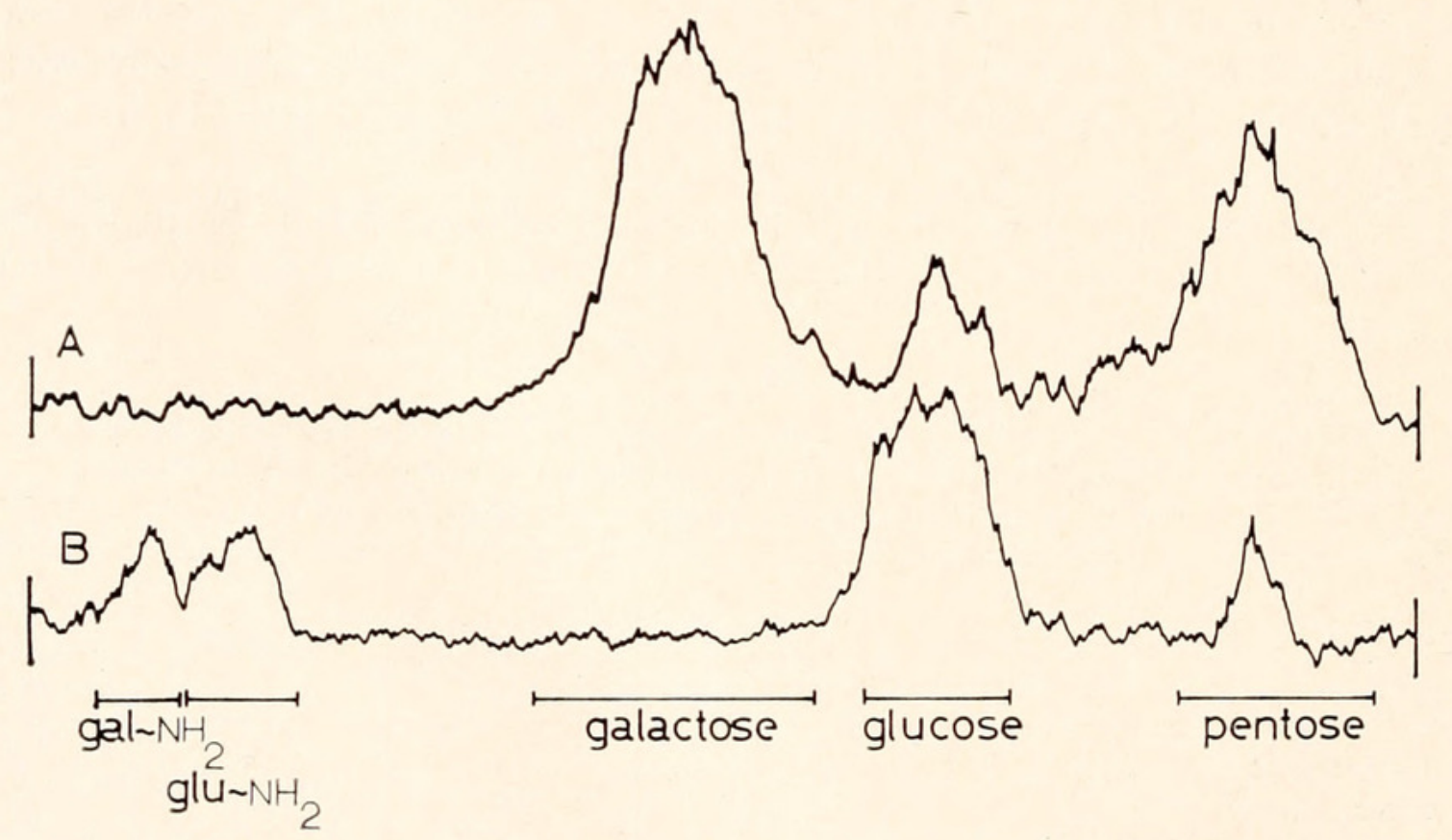

Figure 1. Chromatogram scans of ${ }^{14} \mathrm{C}$-sugars produced by acid hydrolysis of ${ }^{14} \mathrm{C}$-mucus secreted by Tridachiella diomedea (A) and Tridachia crispata (B) during incubation in $\mathrm{NaH}^{14} \mathrm{CO}_{3}$; solvent system, methyl-ethyl-ketone: pyridine: water : acetic acid, (70:15:15:2, v/v), 36 hours on Whatman No. 1 paper; gal- $\mathrm{NH}_{2}$, galactosamine; glu- $\mathrm{NH}_{2}$, glucosamine.

are represented, but the distribution of ${ }^{14} \mathrm{C}$ in these moieties is different in the two species of slugs (Table IV). In Tridachia most of the ${ }^{14} \mathrm{C}$ in mucus is in the glucose moiety, while in mucus from Tridachiella, galactose contained most of the ${ }^{14} \mathrm{C}$, but a smaller amount of ${ }^{14} \mathrm{C}$ was also incorporated into glucose. Taking into account the data on ${ }^{14} \mathrm{C}$ fixed into carbohydrates (Table III) it is suggested that the labeled moieties detected in mucus were derived from chloroplast photosynthesis. Recalling from Tables III and IV that in Tridachia the major soluble labelled sugar is galactose, while the chief labelled component of mucus is glucose, it is tempting to suggest an interconversions of sugars before or during mucus synthesis. Such interconversions may have been less complete in Tridachiella, since galactose is the chief constituent of both the soluble sugar pool and the mucus sugar moieties. Either 
TABLE III

Percentage distribution of ${ }^{14} \mathrm{C}$ in the "intermediary metabolites" fraction from Tridachia crispata, Tridachiella diomedea and Caulerpa sertularioides after photosynthetic ${ }^{14} \mathrm{C}$ fixation. Experimental conditions and numbers of replications as in Table I

\begin{tabular}{l|c|c|c|c|c}
\hline \hline & Glucose & Galactose & Sucrose & $\begin{array}{c}\text { Sugar } \\
\text { phosphates } \\
\text { and } \\
\text { amino acids }\end{array}$ & $\begin{array}{c}\text { Carboxylic } \\
\text { acids }\end{array}$ \\
\hline Tridachia crispata & 5 & 40 & 0 & 39 & 16 \\
Tridachiella diomedea & 9 & 27 & 0 & 48 & 16 \\
Caulerpa sertularioides & 13 & 0 & 29 & 30 & 28 \\
\hline
\end{tabular}

The values given represent ${ }^{14} \mathrm{C}$ in the different compounds as estimated by scanning the developed radiochromatograms.

the two species of slugs have different modes of mucus synthesis, or the same mode which has been observed at different stages of a complex process.

(c) Redistribution of ${ }^{14} \mathrm{C}$ in Tridachia after a pulse of $\mathrm{NaH}^{14} \mathrm{CO}_{3}$. To obtain further information on the possibility of the interconversion of sugars in mucus synthesis, a series of pulse experiments were carried out on Tridachia. Specimens were incubated in $\mathrm{NaH}^{14} \mathrm{CO}_{3}$ in the light for $60 \mathrm{~min}$ and then transferred to unlabelled sea water for up to $24 \mathrm{hr}$. Animals were removed at 1, 3, 6, 9, 12 and 24 hr after the end of the pulse. At each sampling, mucus was collected from the sampled animal which was then killed in methanol-chloroform for subsequent chemical analysis.

Analysis of animals by chemical fractionation showed that immediately after the pulse, most of the ${ }^{14} \mathrm{C}$ in the "intermediary metabolites" fraction was in galactose. This is in agreement with the data in Table III. Over the next $24 \mathrm{hr}$ there was a gradual decline in the relative amount of ${ }^{14} \mathrm{C}$-galactose with a concomitant increase in ${ }^{14} \mathrm{C}$-glucose, which reached a maximum shortly before the maximum specific activity of secreted ${ }^{14} \mathrm{C}$-mucus was attained (Fig. 2 ).

These data strongly support the concept that in Tridachia, ${ }^{14} \mathrm{C}$ fixed by the chloroplasts is rapdily converted to galactose which is then available for conversion to glucose, presumably at or near the site of mucus synthesis. It is then possible to infer that in Tridachiella, less galactose is converted to glucose, and instead, galactose is incorporated directly into mucus.

\section{(3.) Rate of turnover of ${ }^{14} \mathrm{C}$ and ${ }^{3} \mathrm{H}$-leucine in the pedal gland of Tridachia}

(a) Turnover of ${ }^{14} \mathrm{C}$. To gain information on the rate of turnover of chloroplast products in the pedal gland of Tridachia, specimens were incubated in $\mathrm{NaH}^{14} \mathrm{CO}_{3}$

TABLE IV

Percentage distribution of ${ }^{14} \mathrm{C}$ in mucus secreted by Tridachia crispata and

Tridachiella diomedea during incubation in $\mathrm{NaH}^{14} \mathrm{CO}_{3}$ in the light

\begin{tabular}{|c|c|c|c|c|c|}
\hline & Glucose & Glucosamine & Galactose & Galactosamine & 5-C sugar \\
\hline $\begin{array}{l}\text { Tridachia crispata } \\
\text { Tridachiella diomedea }\end{array}$ & $\begin{array}{r}53 \\
8\end{array}$ & $\begin{array}{r}24 \\
0\end{array}$ & $\begin{array}{r}0 \\
56\end{array}$ & $\begin{array}{r}12 \\
0\end{array}$ & $\begin{array}{l}11 \\
36\end{array}$ \\
\hline
\end{tabular}




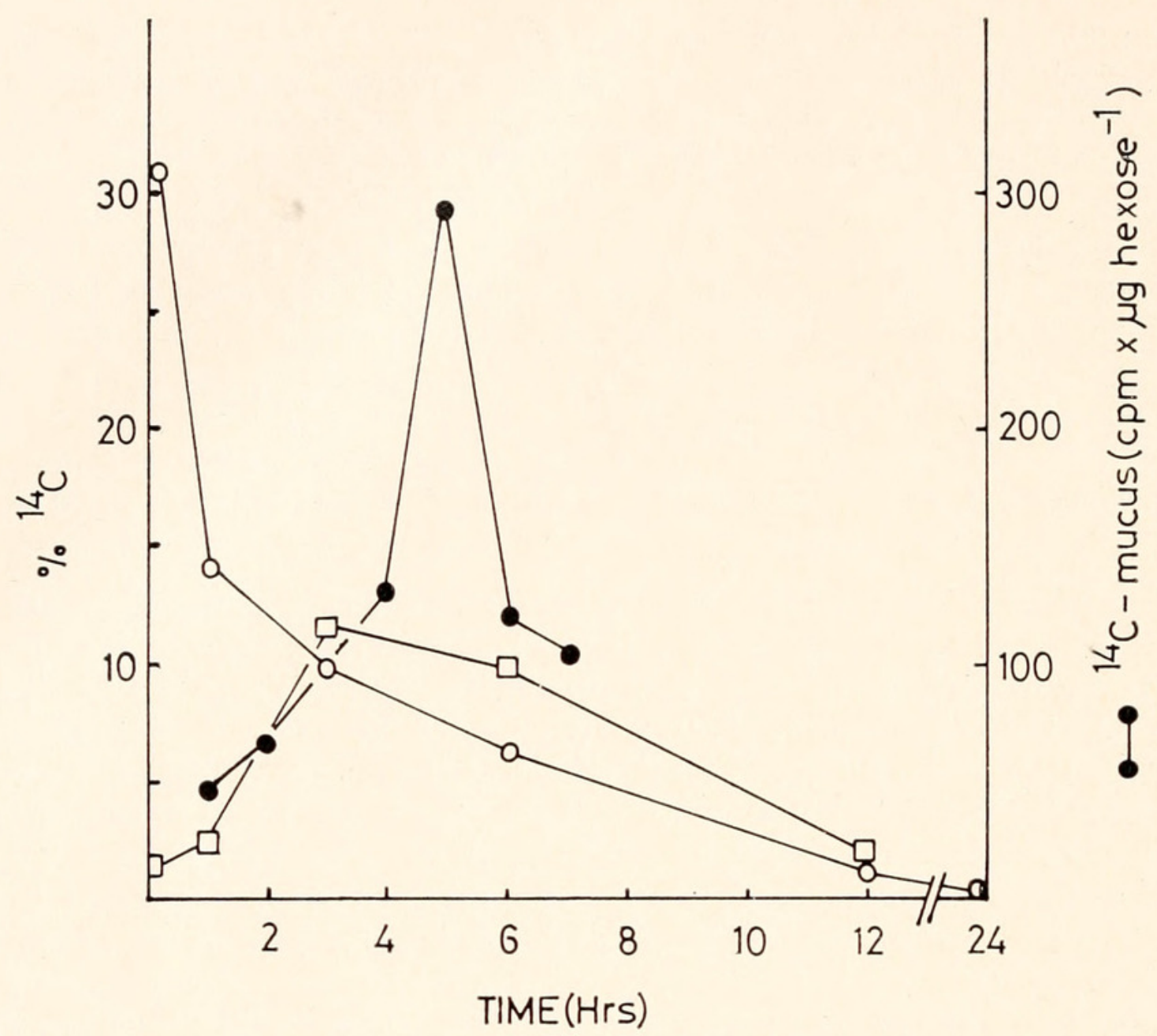

Figure 2. Relationship in Tridachia crispata between ${ }^{14} \mathrm{C}$-galactose, ${ }^{14} \mathrm{C}$-glucose and ${ }^{14} \mathrm{C}$-mucus after one hour "pulse" label in $\mathrm{NaH}^{14} \mathrm{CO}_{3}$ in the light. Labelled glucose and galactose were extracted from the animals, while ${ }^{14} \mathrm{C}$-mucus was collected from that secreted by the animals; $\bigcirc-\bigcirc$, galactose ; $\square-\square$, glucose ; - secreted mucus.

in the light for $1 \mathrm{hr}$ and then transferred to unlabelled sea water. Secreted mucus was collected at hourly intervals beginning immediately after removal of the specimen from the labelled medium, and the specific activity of the ${ }^{14} \mathrm{C}$-mucus determined. Animals were also fixed in Bouins fluid for subsequent analysis by radioautography.

Figure 3 shows that the specific activity of ${ }^{14} \mathrm{C}$-mucus reaches a maximum at about $5 \mathrm{hr}$ and then declines, suggesting a turnover time for ${ }^{14} \mathrm{C}$ of about 10 hours.

When the radioautographs were analyzed, an increasing density of silver grains was observed over the pedal gland up to about $6 \mathrm{hr}$ after the pulse (see also Trench et al., 1969), but very few grains were detected after 12 hr presumably because the labelled mucus had been secreted.

These observations are consistent with the estimate of a 10-12 hour turnover time for carbon in the mucus secreting pedal gland of Tridachia under these experimental conditions.

(b) Turnover of ${ }^{3} \mathrm{H}$-leucine. In view of the observation that the polysaccharide secreted by Tridachia crispata had associated protein, it was of interest to ascertain whether exogenously supplied amino acids could be incorporated into mucus-secreting tissues. Specimens were therefore incubated in ${ }^{3} \mathrm{H}$-leucine for 15 


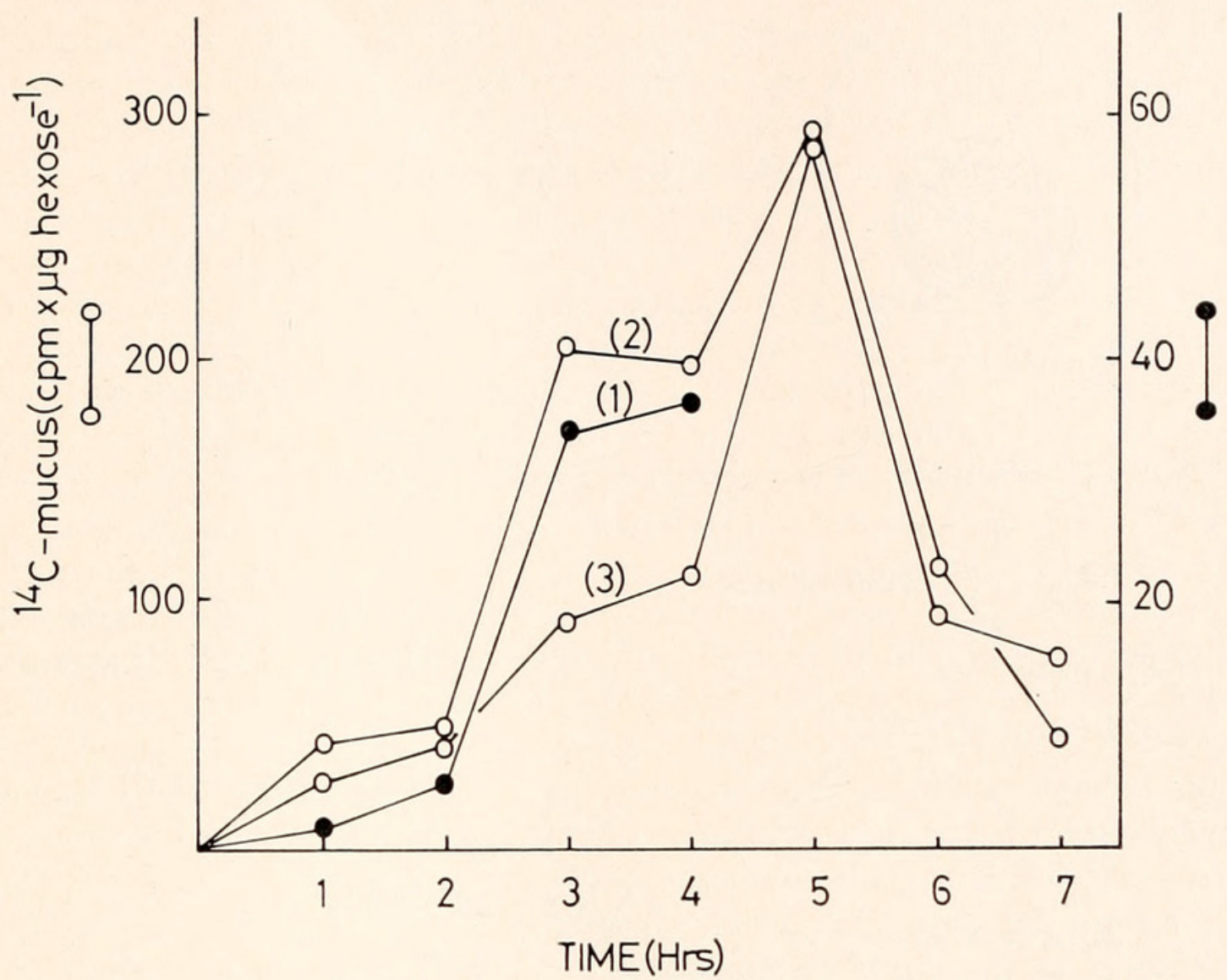

FIgUre 3. Specific activity of ${ }^{14} \mathrm{C}$-mucus secreted by Tridachia crispata after one hour pulse label in $\mathrm{NaH}^{14} \mathrm{CO}_{3}$. Experiment (1) was conducted with ${ }^{14} \mathrm{C}$ at a concentration of 10 $\mu \mathrm{c} / \mathrm{ml}$; experiments (2) and (3) at $50 \mu \mathrm{c} / \mathrm{ml}$.

minutes, and then transferred to unlabeled sea water. Specimens were fixed in Bouin's fluid after 1, 3, 6 and 12 hours in the unlabelled sea water, and the location of radioactivity determined by radioautography.

After 15 minutes in ${ }^{3} \mathrm{H}$-leucine, most of the insoluble radioactivity in Tridachia was associated with the epidermis. After one hour in unlabelled sea water, radioactivity was detected in the end-bulbs of the tubules of the digestive diverticulum and in some (autochromatic) epidermal mucus glands. This contrasts with previous observations which showed that photosynthetic ${ }^{14} \mathrm{C}$ from the chloroplasts was not incorporated into the epidermal mucus glands (Trench, unpublished). Metachromatic mucus cells did not incorporate high levels of radioactivity. Digestive tract tissue also incorporated ${ }^{3} \mathrm{H}$ as did the pedal mucus gland.

After six hours most of the ${ }^{3} \mathrm{H}$ was absent from the epidermal mucus cells, but ${ }^{3} \mathrm{H}$ could still be demonstrated in the pedal mucus gland. After 12 hours however, the pedal gland contained only very little ${ }^{3} \mathrm{H}$, and the only remaining areas of relatively high activity were the end bulbs of the tubules of the digestive diverticulum.

These observations suggest (a) that the incorporation of amino acids into a polysaccharide-protein complex probably occurs in the pedal mucus gland of Triadachia, (b) that leucine may be an important constituent amino acid of the mucus secreted by the pedal mucus gland as well as the epidermal mucus and (c) that the rate of diappearance of ${ }^{3} \mathrm{H}$ from the pedal gland after a pulse "pulse" incorpoation is similar to that of ${ }^{14} \mathrm{C}$. 


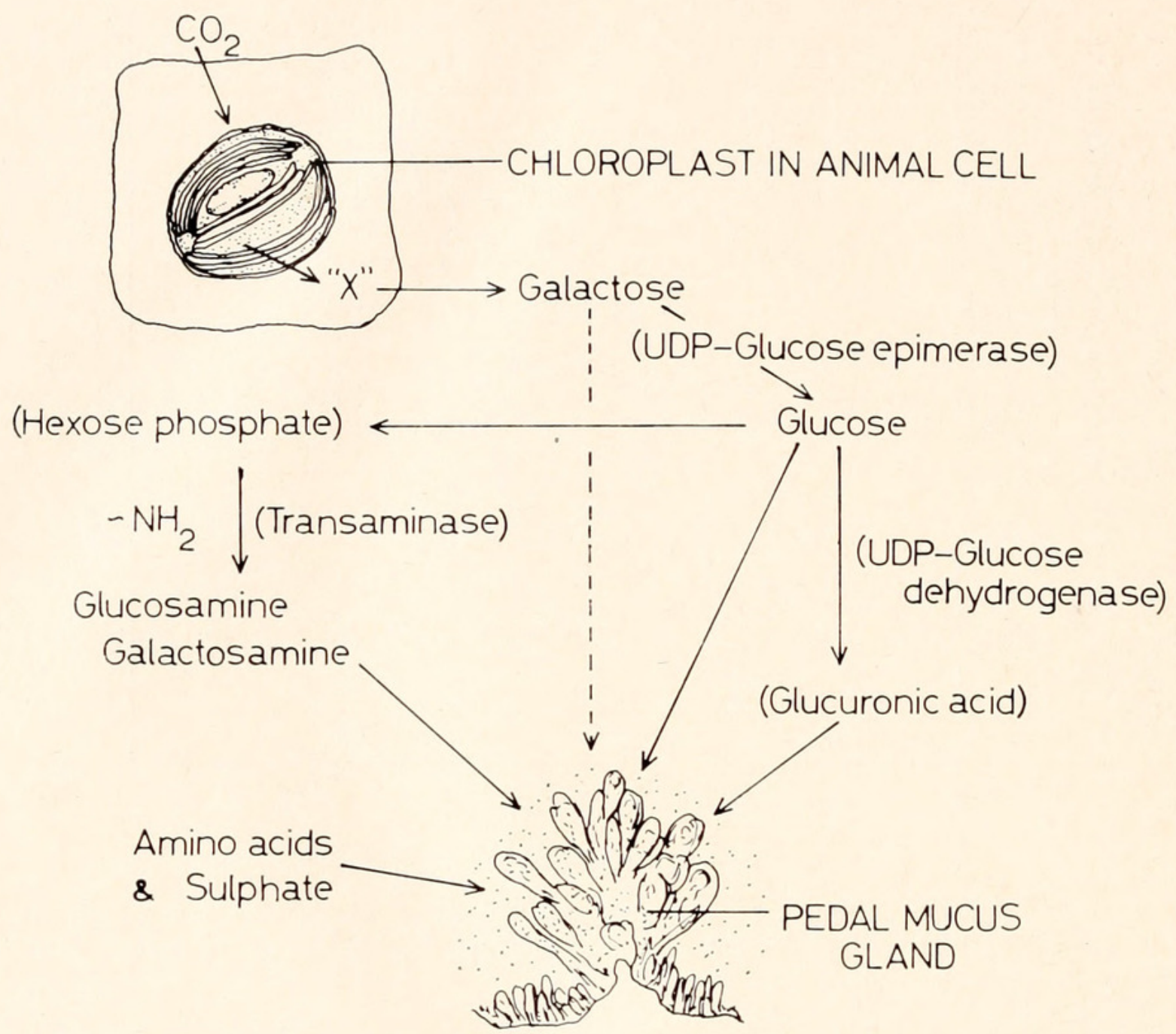

FIGURE 4. Schematic representation of a hypothetical pathway of carbohydrate moving between symbiotic chloroplasts and the pedal mucus gland of Tridachia crispata. Enzymes or intermediates in parenthesis have not been identified in the animals studied. Pathways indicated by dotted lines represent alternative possibilities as indicated by data from Tridachiella and Placobranchus.

\section{Discussion}

The distribution of photosynthetically fixed ${ }^{14} \mathrm{C}$ in Tridachia, Tridachiella and Caulerpa shows marked differences. There could be two reasons for this observation. First, the metabolism of the chloroplasts could become modified in symbiosis and secondly, fixed ${ }^{14} \mathrm{C}$ released by symbiotic chloroplasts may be converted to animal products which are different from those of the plant.

Modification of chloroplast metabolism in animal hosts is suggested by the observation that, in the animals, only trace quantities of ${ }^{14} \mathrm{C}$ are detected in monogalactosyl and digalactosyl digylcerides, while in Caulerpa, a larger proportion of fixed ${ }^{14} \mathrm{C}$ incorporated into lipid is found in the galactolipids. This may indicate that less chloroplast membrane synthesis occurs in the slugs over a six hour period than in the plant. This interpretation would be consistent with the reduced chlorophyll synthesis by chloroplasts in slugs observed by Trench and Smith (1970) if the assumption that chloroplast growth and replication is directly correlated with chlorophyll and galactolipid synthesis is tenable (see Boasson and Laetsch, 1969; Constantopoulos, 1970). 
By contrast, the difference in metabolism of ${ }^{14} \mathrm{C}$-sugars between Caulerpa and the two slugs is more difficult to explain on the basis of modification of chloroplast behavior. Although ${ }^{14} \mathrm{C}$-sucrose was found in the plant but not in the animals, it is not known whether this compound was synthesized in the plant cytoplasm or in the chloroplast. Previous studies have suggested that isolated chloroplasts synthesize sucrose (Tolbert and Zill, 1954; Gee, Joshi, Bils and Saltmann, 1965; Shephard, Levin and Bidwell, 1968; Bidwell, Levin and Shepard, 1970) while others maintain that the cytoplasmic fraction is essential (Walker, 1967). The absence of sucrose in the tissues of the slugs is consistent with the interpretation that sucrose synthetase is a cytoplasmic enzyme in the plant, but there is the possibility that the animal cells could convert sucrose released by the chloroplasts to animal sugars, or directly utilize the precursors of sucrose released by the symbiotic chloroplasts.

In the slugs, ${ }^{14} \mathrm{C}$-galactose and ${ }^{14} \mathrm{C}$-glucose were the major free sugars detected after fixation of ${ }^{14} \mathrm{CO}_{2}$; but whether these are located in the chloroplasts or in the animal tissues is unclear. The presence of free ${ }^{14} \mathrm{C}$-glucose and ${ }^{14} \mathrm{C}$-galactose in slugs with symbiotic chloroplasts after photosynthetic ${ }^{14} \mathrm{CO}_{2}$ fixation appears to be widespread. Greene and Muscatine (in press) also found these labelled sugars in ethanol extracts of the slugs Elysia hedgepethi and Placobranchus ianthobapus after 2.5 hours photosynthesis. The chloroplasts in these slugs are also derived from a siphonous alga. Comparative studies with chloroplasts isolated from the plant and from animals are currently being undertaken in the hope of clarifying the problem of distinguishing between substances synthesized and retained by the chloroplasts and those released and metabolized by the cell cytoplasmic enzyme systems.

The difference of incorporation of ${ }^{14} \mathrm{C}$ into insoluble compounds in the animals and the alga is also striking. Plant material was readily hydrolyzed in $1 \mathrm{M} \mathrm{HCl}$, while animal material was more resistant. This may be a reflection of protective $\mathrm{NH}_{2}$ groups in sugar amines in animal polysaccharides (Neuberger and Marshall, 1966). Acid hydrolysis of ${ }^{14} \mathrm{C}$-labelled animal material yielded glucose, galactose and a pentose (similar to the products of secreted ${ }^{14} \mathrm{C}$-mucus). These sugars were probably derived, at least in part, from mucus within the animal. Acid hydrolysis of ${ }^{14} \mathrm{C}$-labelled plant insoluble material yielded glucose, galactose and mannose, which may have been derived in part from "cell wall" material, since Caulerpa is known to be rich in polysaccharides containing galactose and mannose (Percival and McDowell, 1967).

The incorporation of fixed ${ }^{14} \mathrm{C}$ into mucus is clear evidence that the animals can metabolize products released by the chloroplasts, but there is no data on how much carbon is provided by the chloroplasts for animal mucus synthesis. However, the observation that animals with chloroplasts secreted three to four times as much mucus as those without suggests that carbon supply from the chloroplasts is quantitatively important in mucus synthesis. The very rapid turnover of fixed ${ }^{14} \mathrm{C}$ in the mucus secreting pedal gland, demonstrated in the experiments, further supports this view.

The carbohydrate composition of mucus secreted by Tridachia and Tridachiella was generally similar. After hydrolysis, the sugars detected were glucose, glucosamine, galactose, galactosamine, and an unidentified pentose. Following incubations of the animals in $\mathrm{NaH}^{14} \mathrm{CO}_{3}$, photosynthetically fixed ${ }^{14} \mathrm{C}$ became chemically 
incorporated into secreted mucus as ${ }^{14} \mathrm{C}$-sugars. Thus, as previously suggested by Trench et al., (1970) it is possible that one of the forms in which carbon moves from the chloroplasts to the animals is as sugar or sugar precursors (see also Smith, Muscatine and Lewis, 1969). The animals very likely possess the enzyme systems necessary for their interconversions. A hypothetical scheme depicting this is shown in Figure 4. Although the mode of transfer is not known, metabolites very likely enter the haemocoel and are distributed throughout the organism. The sites at which the intercoversions may occur are also unknown, though from data available from other systems (see Hunt, 1970), it is possible that an epimerase system may be located near the cells containing the chloroplasts, while other epimerases, transaminases and dehydrogenases may be associated with the mucus secreting cells themselves. Thus, the sugar amines and sugar acids may actually be formed in the Golgi apparatus of the cells that comprise the pedal gland (see Neutra and Leblond, 1966).

There is as yet no direct measurement of the proportion of fixed ${ }^{14} \mathrm{C}$ released by symbiotic chloroplasts. However, since $30 \%$ of the total ${ }^{14} \mathrm{C}$ fixed was recovered in mucus after $5 \mathrm{hr}$ in the pulse label experiment (Fig. 2), and since mucus is obviously an animal product, then a minimum of $30 \%$ of the carbon fixed by the chloroplasts in Tridachia is released to the animal. It should be borne in mind however, that mucus synthesis is not the only fate of chloroplast photosynthetic ${ }^{14} \mathrm{C}$, as indicated by the radioautographic studies of Trench et al., (1969). Neither is there any available data on how much of the chloroplast products is used in respiratory pathways. With the data available, it is possible to make an estimate of the proportion of fixed ${ }^{14} \mathrm{C}$ released if the following three assumptions are valid; (i) that free galactose (in the "intermediary metabolites" fraction) is an animal product made from some unknown precursor released from the chloroplasts (see Fig. 4) ; (ii) that galactose itself is a precursor used in the synthesis of mucus, and (iii) that the chloroplasts do not themselves synthesize large quantities of ${ }^{14} \mathrm{C}$-polysaccharide (unpublished results of preliminary experiments on isolated chloroplasts suggest that this may in fact be the case). From these assumptions, it is possible to calculate from the data in Tables I and III that after $6 \mathrm{hr}$ photosynthesis in $\mathrm{H}^{14} \mathrm{CO}_{3}{ }^{-}, 51 \%-54 \%$ of the total ${ }^{14} \mathrm{C}$ fixed in Tridachia and Tridachiella can be found in free galactose and mucus. It is therefore suggested that at least half of the carbon fixed photosynthetically by symbiotic chloroplasts is released to the tissues of the host animal.

The detection of free sugars and amino sugars in hydrolysates of mucus does not provide proof that these occur as the unsubstituted hexoses in native mucus. For example, $\mathrm{N}$-sulphate, $\mathrm{O}$-sulphate or $\mathrm{N}$-acetyl groups would have been removed during acid hydrolysis. Similarly, the presence of a pentose in hydrolysates of mucus could be an indication of the occurrence of uronic acid in the native mucus, since under conditions of acid hydrolysis, uronic acids may be decarboxylated (Brimacombe and Webber, 1964).

Similar to the mucus secreted by Placobranchus (Trench et al., 1970) mucus secreted by Tridachia and Tridachiella appears to contain a protein moiety associated with the polysaccharide polymer. The observations on the incorporation of ${ }^{3} \mathrm{H}$-leucine into mucus-secreting tissues by Tridachia suggest the existence of a polysaccharide-protein complex. Most studies of mucus from molluscs have reported the presence of protein (Brimacombe and Webber, 1964; Masamune and 
Yosozawa, 1965), and that from Tridachia and Tridachiella appears to conform to the pattern. Although no details of the structure of mucus from the pedal gland of Tridachia and Tridachiella can be presented, it is very likely a sulphated acid polysaccharide associated with protein.

It is important to stress that the experiments described represent studies of intact systems containing chloroplasts, and not the isolated chloroplasts themselves. To determine the fate of fixed ${ }^{14} \mathrm{C}$ in the plant and animal systems, it would be advantageous to show the form in which ${ }^{14} \mathrm{C}$ is released from the chloroplasts in animal and plant cells. Experiments designed to study these problems are now in progress.

We would like to thank the late Professor T. F. Goreau for providing support for the first and second authors during the summer of 1969, as well as providing facilities and space at the Discovery Bay Marine Laboratory. We also express our gratitude to Mr. Bob Peterson of the Foundation for Ocean Research for making facilities available on board the R. V. Dolphin, and to Dr. J. R. Clarke of the Department of Agricultural Sciences, Oxford, for permitting extensive use of his histological equipment. The technical assistance of Miss J. Elizabeth Boyle, and Mr. John F. Farrar with GLC analyses is gratefully acknowledged. Drs. D. C. Smith, G. Gooday and D. H. Lewis critically read early drafts of this manuscript, and we are very grateful for their suggestions and discussions.

Research was supported in part by ONR-N00014-69-C-0152, and NSF-GB6438, in Jamaica and Los Angeles, respectively. Work in Oxford was supported by the Science Research Council (U. K.).

\section{SUMMARY}

1. The products of photosynthetic ${ }^{14} \mathrm{CO}_{2}$ fixation by symbiotic chloroplasts in the marine sacoglossan opisthobranch gastropods Tridachia crispata (Mörch) and Tridachiella diomedea (Bergh) were compared with those of the siphonous green alga Caulerpa sertularioides.

2. After six hours photosynthesis in $\mathrm{NaH}^{14} \mathrm{CO}_{3}$, the distribution of ${ }^{14} \mathrm{C}$ in organic compounds in the two slugs was similar, but different from that in the plant.

3. The major soluble ${ }^{14} \mathrm{C}$-labelled carbohydrates found were glucose and sucrose in the plant and glucose and galactose in the slugs.

4. The plant contained appreciable ${ }^{14} \mathrm{C}$-galactolipids, while little ${ }^{14} \mathrm{C}$ could be detected in galactolipids in chloroplasts in the animals. In both slugs and alga, large quantities of ${ }^{14} \mathrm{C}$ were incorporated into polysaccharide.

5. After pulse-labelleing for one hour, ${ }^{14} \mathrm{C}$-galactose was the major soluble carbohydrate detected in Tridachia. Subsequently, the galactose decreased with a concomitant increase in ${ }^{14} \mathrm{C}$-glucose. Thereafter maximum ${ }^{14} \mathrm{C}$-glucose was detected in secreted ${ }^{14} \mathrm{C}$-mucus suggesting utilization of galactose and glucose in mucus synthesis.

6. It is estimated that the rate of turnover of ${ }^{14} \mathrm{C}$ in the mucus-secreting pedal gland of Tridachia is 10-12 hours, suggesting that chloroplast products play an important role in animal mucus synthesis. 


\section{LITERATURE CITED}

Bassham, J. A., And M. Calvin, 1957. The Path of Carbon in Photosynthesis. Prentice Hall, Englewood Cliffs, New Jersey, 104 pp.

Bidwell, R. G. S., W. B. Levin and D. C. Shephard, 1970. Intermediates of photosynthesis in Acetabularia mediterrania chloroplasts. Plant Physiol., 45: 70-75.

Block, R. J., E. L. Durram and G. Zweig, 1958. Paper Chromatography and Paper Electrophoresis. Academic Press, New York, 710 pp.

Boasson, R., and W. M. Laetsch, 1969. Chloroplast replication and growth in Tobacco. Science, 166: 749-751.

Brimacombe, J. S., and J. N. Webber, 1964. Mucopolysaccharides. Elsevier Publishing Co., Amsterdam, London, New York, 181 pp.

Constantopoulos, G., 1970. Lipid Metabolism of Manganese-deficient Algae. I. Effect of manganese deficiency on the greening and lipid composition of Euglena gracillis Z. Plant Physiol., 45 : 76-80.

Dubois, M., K. A. Gillies, J. K. Hamilton, P. A. Rebers and F. Smith, 1956. Colourimetric method for determination of sugars and related substances. Anal. Chem., 28: $350-356$.

Gee, R., G. Joshi, R. F. Bils and P. Saltman, 1965. Light and dark ${ }^{14} \mathrm{CO}_{2}$ fixation by spinach leaf chloroplasts. Plant Physiol., 40: 89-96.

Gibbons, R. A., And M. L. Wolfrom, 1962. Hydrolytic sensitivity of the sulfoamino group in heparin and in model compounds. Arch. Biochem. Biophys., 98: 374-378.

Greene, R. W., 1969. Symbiosis in sacoglossan opisthobranchs. Ph.D. thesis, University of California at Los Angeles, 120 pp.

Greene, R. W., 1970. Symbiosis in sacoglossan opisthobranchs: functional capacity of symbiotic chloroplasts. Marine Biology, 7 : 138-142.

Hunt, S., 1970. Polysaccharide-Protein Complexes in Invertebrates. Academic Press, London, New York, 329 pp.

Kawaguti, S., and T. Yamasu, 1965. Electron microscopy on the symbiosis between and elysioid gastropod and chloroplasts of a green alga. Biol. J. Okayama Univ., 11: 57-65.

Loughman, B. C., and R. Martin, 1957. Methods and Equipment for the study of the incorporation of phosphorus by intact Barley plants in experiments of short duration. J. Exp. Bot., $23: 272-279$.

Masamune, H., and Z. Yosizawa, 1965. Biochemical studies on carbohydrates. CXC. Sugar components in snail mucus mucin. Tohoku J. Exp. Med., 65: 57-62.

Neuberger, A., and R. D. Marshall, 1966. Pages 190-234 in A. Gottschalk, Ed., Glycoproteins, Their Composition, Structure and Function. Ch. 8, Elsevier Publishing Co. Amsterdam, London, New York.

Neutra, N., And C. P. Leblond, 1966. Synthesis of carbohydrate of mucus in the Golgi complex as shown by electron microscope radioautography of goblet cells from rats injected with glucose- ${ }^{3} \mathrm{H}$. J. Cell Biol., $30: 119-136$.

Nichols, B. W., 1970. Comparative lipid biochemistry of photosynthetic organisms. Pages 105-118 in J. B. Harborne, Ed., Phytochemical Phylogeny. Academic Press, London.

Percival, E., And R. H. McDowell, 1967. The Chemistry and Enzymology of Marine Algal Polysaccharides. Academic Press, London and New York, 219 pp.

Shephard, D. E., W. B. Levin and R. G. S. Bidwell, 1968. Normal photosynthesis by isolated chloroplasts. Biochem. Biophys. Res. Commun., 32: 413-420.

Smith, D. C., L. Muscatine and D. H. Lewis, 1969. Carbohydrate movement from autotrophs to heterotrophs in parasitic and mutualistic symbiosis. Biol. Rev. Cambridge, $44: 17-90$.

TAYlor, D. L., 1967. The occurrence and significance of endosymbiotic chloroplasts in the digestive glands of herbivorous opisthobranchs. J. Phycology, 3: 234-235.

TAYlor, D. L., 1968. Chloroplasts as symbiotic organelles in the digestive gland of Elysia viridis. J. Mar. Biol. Ass. U. K., 48: 1-16.

Taylor, D. L., 1970. Chloroplasts as symbiotic organelles. Int. Rev. Cytol., 27: 29-64.

TAYLOR, D. L., 1971b. Photosynthesis of symbiotic chloroplasts in Tridachia crispata (Bergh). Comp. Biochem. Physiol., 38A : 233-236. 
Thompson, G. A., 1965. Pages 64-88 in J. Bonner and J. E. Varner, Eds., Plant Biochemistry. Chapter 5. Academic Press, New York.

Tolbert, N. E., And L. P. Zill, 1954. Photosynthesis by protoplasm extruded from Chara and Nitella. J. Gen. Physiol., $37: 575-588$.

Trench, M. E., R. K. Trench and L. Muscatine, 1970. Utilization of photosynthetic products of symbiotic chloroplasts in mucus synthesis by Placobranchus ianthobapsus (Gould), Opisthobranchia, Sacoglossa. Comp. Biochem. Physiol., 37 : 113-117.

Trench, R. K., 1969. Chloroplasts as functional endosymbionts in the molluse Tridachia crispata (Bergh), Opisthobranchia, Sacoglossa. Nature, 222: 1071-1072.

TrEnCH, R. K., 1971a. The physiology and biochemistry of zooxanthellae symbiotic with marine coelenterates. I. The assimilation of photosynthetic products of zooxanthellae by two marine coelenterates. Proc. Roy. Soc. London Series B, 177 : 225-235.

Trench, R. K., 1971b. The physiology and biochemistry of zooxanthellae symbiotic with marine coelenterates. II. Liberation of fixed ${ }^{14} \mathrm{C}$ by zooxanthellae in vitro. Proc. Roy. Soc. London Series B, 177 : 237-250.

Trench, R. K., and D. C. Smith, 1970. Synthesis of pigment in symbiotic chloroplasts. Nature, 227 : 196-197.

Trench, R. K., R. W. Greene and B. G. Bystrom, 1969. Chloroplasts as functional organelles in animal tissues. J. Cell Biol., 42: 404-417.

von Holt, C., And M. von Holt, 1968b. The secretion of organic compounds by zooxanthellae isolated from various types of Zoanthus. Comp. Biochem. Physiol., 24: 83-92.

Walker, D. A., 1967. Photosynthetic activity of isolated pea chloroplasts. Pages 53-69 in T. W. Goodwin, Ed., Biochemistry of Chloroplasts. Vol. II. Proc. N.A.T.O. Advanced Study Institute, Aberystwyth, 1965. 


\section{$2 \mathrm{BHL}$ Biodiversity Heritage Library}

Trench, Robert Kent, Trench, Merriley E, and Muscatine, Leonard. 1972. "SYMBIOTIC CHLOROPLASTS; THEIR PHOTOSYNTHETIC PRODUCTS AND CONTRIBUTION TO MUCUS SYNTHESIS IN TWO MARINE SLUGS." The Biological bulletin 142, 335-349. https://doi.org/10.2307/1540236.

View This Item Online: https://www.biodiversitylibrary.org/item/17312

DOI: https://doi.org/10.2307/1540236

Permalink: https://www.biodiversitylibrary.org/partpdf/7001

\section{Holding Institution}

MBLWHOI Library

\section{Sponsored by}

MBLWHOI Library

\section{Copyright \& Reuse}

Copyright Status: In copyright. Digitized with the permission of the rights holder.

License: http://creativecommons.org/licenses/by-nc-sa/3.0/

Rights: https://biodiversitylibrary.org/permissions

This document was created from content at the Biodiversity Heritage Library, the world's largest open access digital library for biodiversity literature and archives. Visit BHL at https://www.biodiversitylibrary.org. 